\title{
Identity-supportive nursing of patients with dementia in nursing homes
}

\section{Abstract}

This article aims to explore how nursing can support a sense of continuity and identity in patients with advanced dementia disease, living in nursing homes. Fourteen carers and managers in two nursing homes in northern Norway were interviewed. The analysis and discussion are based on the theoretical concepts of identity, continuity and person-centred nursing. This study concludes that an awareness of an individual's earlier life may be practically expressed in person-centred nursing, and may support continuity in the patient's life even after moving into the nursing home.

Documentation, professional development, and the organisation of the nursing home are important elements to ensure this awareness. Whilst on-going competence building in the nursing home is necessary, the value of local knowledge among the staff is also emphasized. Before a person moves to a nursing home it would be useful for staff to visit the person's home, gather information from the person and their family, and establish a relationship that can give a sense of security. In the nursing home, a feeling of belonging and identity can be enhanced through daily activities, personal care and mealtimes. The importance of reinforcing a sense of belonging in patients with dementia disease is highlighted.

\section{Keywords}

Vulnerability, elderly people, life course, belonging, person-centred nursing

\section{Introduction}

This article aims to explore how nursing can support a sense of continuity and identity in patients with advanced dementia disease (DD), living in nursing homes. Today, approximately 70.000 people in Norway have DD. About half of those live in nursing homes (1). The majority suffer from an advanced stage of DD, as the tendency is for elderly ill persons to live in their own homes as 
long as possible.

Continuity and identity are serious challenges to nursing care, since DD causes shifting disruptions in a person's memory. The use of names, concepts and language becomes increasingly uncertain, and the familiar and accustomed become strange. The advance of the disease, and the leaving of familiar surroundings to move into a nursing home, can make it difficult to remember experiences that have influenced one's identity $(2,3)$. The person is in danger of having to live as a stranger in the world.

The premise of this article is that patients' life stories are important to nursing home practice, particularly for patients with advanced DD. For nursing to sustain a measure of continuity between the patient's earlier and present life, carers need to know something of the person's life. The article explores how nursing carers and managers of patients with DD may use familiarity with the patients' life stories in their approach to nursing.

Many studies have shown the significance of understanding the patient as a person $(4,5,6,7,8,9$, 10). Their findings indicate that individual nursing, including activities that the patient used to engage in, reinforce the sense of identity in patients with DD.

This study is a part of a larger study investigating the significance of belonging in one's own life for elderly people with DD who live in nursing homes. Patients with DD and their close relatives have been interviewed about activities and values of importance to them in earlier and present life (2, $11)$. 


\section{Providing nursing for patients with dementia}

Identity and continuity are linked to both internal, emotional processes, and external circumstances $(2,11)$. Analytically, internal continuity is said to relate to feelings, values, preferences and a sense of being connected to the past, while external continuity may be said to relate to physical and social surroundings, roles and activities (12). External identity defines the person, while the internal identity is related to values: where we are in life, what we are, and what we believe in $(13,14)$. On the other hand, our internal values evolve through external experiences, and internal identity finds its expression in the stories we relate from our lives $(15,16)$. Kroger $(17)$ points out that identity is flexible, and may change through a person's life experiences. Since DD can challenge a person's identity and continuity $(12,17)$, carers need to know, and consider, some of the important stories from the patient's life (3).

This study is based on a person-centred approach to nursing for patients with DD, with focus on the patient's life story, habits and values $(18,19,20,3,21,22)$. Knowledge of the patient's life history may help carers to understand behaviour. Person-centred nursing for patients with DD means that the persons are valued, their rights are safeguarded, their perspective is appreciated and their subjective experiences are recognized. Functional relationships are crucial in person-centred nursing. Both patient and carer are valued and respected. Martinsen (23) argues that relationships and dependency are fundamental in discussing values, and that nursing has relational, practical and moral dimensions. Knowledge, skills and organisation are essential for the carer to meet the patient $(19,22,24)$. Managers have a responsibility to value and respect staff, and to organise resources for implementing person-centred nursing. It is important to be aware of the challenges faced by the patient with DD $(25,22)$. 


\section{Methods and participants}

To explore how nursing can support a sense of continuity and identity in patients with advanced

DD, fourteen carers and managers were interviewed individually, in groups of two, and in one focus group. The carers included both registered nurses and nursing assistants. The managers were registered nurses. An interview guide was used, inviting the participants to discuss the study question in relation to their work experiences. The interviews were conducted in the form of openended conversations. This part-study aims to elicit carers' and managers' own perspectives on values, practices, and reasons, regarding continuity in life with advanced DD. The methods chosen offer scope for the participants' - to express their own points of view and opinions (26). This design is in accordance with the person-centred approach, in which also the carers' experiences are valued.

The interviewees were selected from two nursing homes in northern Norway, one in an urban setting and one in a rural area. This selection was made to broaden the approach, as the local social structure may have impacts on identity and continuity in the nursing home. Managers in each nursing home recruited participants (P1-P14). All the participants were female. They were managers at institution and unit level, and carers from four units. Two of the units were special units for patients with DD, the others housed patients both with and without DD. Participants were asked about their knowledge of patients' backgrounds, and what consequences patients' earlier lives had for their life in the nursing home. Documentation, information gathering, relevant competence development, and the organization of the nursing home, were also discussed in the interviews. The managers had worked in nursing homes for over ten years. Carers' work experience varied from 3 to 22 years, average 12. Both younger and older carers participated. Participants read the interview guide before the interview.

The plan was to conduct a minimum of four focus group interviews. Focus group interview is an 
appropriate method as it allows participants to together reflect on their experiences in a dialogue, which allows experiential knowledge to emerge (27). At the urban nursing home, the focus group interview had to be cancelled due to staff absence. Only one focus group interview was conducted with eight carers from the rural nursing home. Four individual interviews as described by Kvale (26) were carried out with two managers and two carers from the urban nursing home, and two managers from the rural nursing home were interviewed together. The interviews were transcribed verbatim. It seemed appropriate to interpret all the data in the same analysis as the participants had discussed the same questions.

The interviews were analysed using content analysis $(28,29)$. According to Schreiner (29), this is an appropriate analysis tool for the study of work experiences. Meaning units - constellations of statements relating to the same meaning - were identified across the whole transcribed text, condensed, and coded with terms close to the text. The coded meaning units were grouped according to content. Subthemes were formulated as headings. The themes that constitute the findings of the study, were formulated through re-discussing the whole interview material with the sub-themes against the research question: How can nursing support a sense of continuity and identity in patients with advanced DD? The first and third authors examined the content analysis to corroborate the interpretation.

Table 1 Examples from the content analysis of interviews with managers and caregivers of persons with DD in nursing homes in northern Norway.

\begin{tabular}{|l|l|l|l|l|}
\hline Meaning unit & $\begin{array}{l}\text { Condensed } \\
\text { meaning unit }\end{array}$ & Code & Subtheme & Theme \\
\hline $\begin{array}{l}\text { It will be safe for } \\
\text { relatives, because even } \\
\text { though they may not } \\
\text { know you or me, they } \\
\text { always know one or five } \\
\text { of the other carers who } \\
\text { work here ..., have } \\
\text { visited here or ..., they } \\
\text { know someone who has } \\
\text { had a family member in }\end{array}$ & $\begin{array}{l}\text { There is a security } \\
\text { for patients and } \\
\text { relatives in } \\
\text { knowing someone } \\
\text { who works, has } \\
\text { worked, or has } \\
\text { some other } \\
\text { connection to the } \\
\text { nursing home. }\end{array}$ & $\begin{array}{l}\text { Familiarity } \\
\text { contributes to } \\
\text { security and a } \\
\text { sense of } \\
\text { belonging. }\end{array}$ & $\begin{array}{l}\text { Personal } \\
\text { acquaintance in } \\
\text { small } \\
\text { municipalities }\end{array}$ & $\begin{array}{l}\text { Local personal } \\
\text { acquaintance } \\
\text { and belonging }\end{array}$ \\
\end{tabular}




\begin{tabular}{|l|l|l|l|l|}
\hline $\begin{array}{l}\text { the nursing home ..., so } \\
\text { that the patients ..., or } \\
\text { relatives know what } \\
\text { they are going to meet. }\end{array}$ & & & \\
\hline $\begin{array}{l}\text { People who work here } \\
\text { today have in fact cared } \\
\text { for someone at home, } \\
\text { and so when that person, } \\
\text { a mother or a father }(. . .) \\
\text { has died, they have } \\
\text { applied for a job at the } \\
\text { nursing home. Because } \\
\text { they may have } \\
\text { accompanied them here } \\
\text { in the final phase and } \\
\text { they have seen ..., and } \\
\text { wanted to work here. } \\
\text { norsing home } \\
\text { have previously } \\
\text { for care of a } \\
\text { person in their } \\
\text { own home. When } \\
\text { the person they } \\
\text { had cared for } \\
\text { moved to the } \\
\text { nursing home or } \\
\text { died, they wished } \\
\text { to work at the } \\
\text { nursing home. }\end{array}$ & $\begin{array}{l}\text { Personal } \\
\text { experience of } \\
\text { familiarity } \\
\text { motivates care } \\
\text { in the nursing } \\
\text { home. }\end{array}$ & $\begin{array}{l}\text { Valuable } \\
\text { competence }\end{array}$ & $\begin{array}{l}\text { Local personal } \\
\text { acquaintance } \\
\text { and belonging }\end{array}$ \\
& & & \\
\hline
\end{tabular}

Table 2 Overview of themes and subthemes obtained by content analysis of interviews with managers and caregivers of persons with DD in nursing homes in northern Norway.

\begin{tabular}{|l|l|}
\hline Theme & Subtheme \\
\hline $\begin{array}{l}\text { Local personal acquaintance and } \\
\text { belonging }\end{array}$ & Personal acquaintance in small municipalities \\
\hline & Valuable competence \\
\hline The patient's life story & Documenting the patient's life story \\
\hline $\begin{array}{l}\text { The significance of the patient's } \\
\text { earlier life in the nursing home }\end{array}$ & Cooperation with family members in documenting the life story \\
\hline & The patient's identity and development of DD \\
\hline $\begin{array}{l}\text { A more challenging working day in } \\
\text { the nursing home }\end{array}$ & $\begin{array}{l}\text { The significance of familiarity for calm, well-being and } \\
\text { conversation }\end{array}$ \\
\hline & Moving into the nursing home: Inadequate preparation \\
\hline & A tighter framework \\
\hline
\end{tabular}

When conducting research, cooperation with participants is an ethical responsibility. The study aimed at treating the nursing managers' and carers' reflections and work experience with respect, while conducting a critical discussion of the findings. The project has been approved by the Norwegian Social Sciences Data Service. 


\section{Findings}

\section{Local personal acquaintance and belonging}

\section{Personal acquaintance in small municipalities}

Nursing in the rural nursing home presented some characteristic possibilities that the urban nursing home did not share. The municipal administration, as well as the carers and the managers, had personal knowledge of the patients. One manager said: "It is easier to say no to a stranger than to "Anna" who we know where lived and had been married to" (P9). Managers believed that this protected the nursing home against cutbacks, and meant that the value of their work was recognized. One manager said: "Most people in our municipality have a positive impression about residential care services" (P10). Because the managers had worked many years in the nursing home, the local inhabitants knew who they were; "and you put more effort into finding good solutions" (P9). They said that they survive because they know people. Usually, some members of staff in the rural nursing home knew the patient before the move to the nursing home. The relationship was often better when a carer he or she already knew, assisted the patient. Many patients had also previously visited the nursing home.

The carers from the rural nursing home opined that a person who became a patient in the nursing home deserved to be met with dignity and respect, even when the earlier relationship had not been good.

\section{Valuable competence}

The managers in the rural nursing home recruited and trained many carers from the local area. They valued the familiarity the carers had with the patients, local history and traditions. One of them said: "Nursing is very much about life, life stories, and recognising who the person with DD has been" (P9). 


\section{The patient's life story}

\section{Documenting the patient's life story}

Local knowledge was not emphasized by the participants from the urban nursing home, although both nursing homes valued ties to the community. Both worked with local volunteers, nursery- and primary schools. The urban nursing home invited relatives and local people to events in order to recruit volunteers. They cited the patient, family members, and professionals from other institutions as sources of information about the patient's life. They observed the patient and collected information as needed.

Both nursing homes documented the patient's family circumstances, names of close family members, health, functional level, where the patient had lived, what they had worked with, hobbies, religious beliefs and habits related to the demands and activities of daily life. The names of parents and siblings were especially important to know when the patient talked about people from the past. One carer said: "It is important to know about traumatic events in the past. This could be important if the patient became anxious without an apparent cause" (P13). In relation to documentation of the patient's social situation and function, they emphasized that it was important to know how the patient got on with others.

It was said that new carers found it difficult to orientate themselves, because the information about patients could be insufficient for the carer to fully understand the patient and give appropriate care. One carer said: "The carers should be allocated more time to update the patients' care plan" (P13). Some patients could not or would not give information about their past. One carer said: "We often have to feel our way to find out what they like and don't like" (P14).

\section{Cooperation with family members in documenting the life story}

Staff in both nursing homes encouraged relatives to fill out a form; "my history," with 
comprehensive information about the patient's life, childhood, confirmation, profession, interests, events and "things we should know". One manager said: "The aim is to fill out the form of all patients, but it is not all the patients that have "my history" filled out" (P11). They discussed whether the form was difficult to fill out, whether relatives needed guidance from carers, or whether a concrete example would help. Relatives were also asked to make albums with photographs from the patient's life and of family members.

\section{The significance of the patient's earlier life in the nursing home}

\section{The patient's identity and development of DD}

One carer said: "What they've worked with is easily seen" (P11). She meant that one could see from the body and behaviour of the patient whether they had worked hard physically, had been fishermen, nurses or had other employment. Many of the patients were used to being out of doors: "There is a lot of sitting inside now, for those who once liked to be outside" (P11). One carer pointed out that it was unsatisfactory for a patient who had been used to being in the open air to be left sitting in a room without a view.

Several carers said that patients did not wish to join in activities they had earlier enjoyed. One said: "It's not easy to get patients with DD to join in with activities. It seems like they don't want to..." (P14).

Patients were seen as people with ingrained habits:

The patient can have sleeping problems. He can wake up in the night and be very restless, wander around and wake the other patients. The cause can be something small, maybe he is used to sleeping in a dark room and can't sleep with the light on (P11).

It could be difficult for patients to maintain their interests and habits in the nursing home: "The life that the patient has had in their own home is changed" (P13). The patient may have lived alone 
through a long life; in the nursing home they have to become accustomed to the other patients. This was difficult to understand for patients with DD, and conflicts could arise.

\section{The significance of familiarity for calm, well-being and conversation}

The carers and managers in the rural nursing home thought that familiarity with the patient's background promoted calmness, conversation, well-being and a good atmosphere in the unit. One manager summarized that knowledge of the patient's life story was important to "give them a richer life in the nursing home, bolster their self-image and affirm them in what they have been before (...). You are familiar with how people earned a living, church weekends, serious accidents, and the names of boats" (P9).

The managers in the rural area explained that when the patients sat together at the breakfast table, the conversational themes could be related to the season, for example berry picking. One of them also said:

When patients with DD have a problem with language and only remember certain things from their past, then if you know the patient well through a long life, sometimes one word is enough for you to understand what they want to say (P10).

The same manager emphasized the carers' practical experience in the social space between patients:

The staff is very important in the dialogue that takes place. They are the buffers. Patients with DD seldom take the initiative to talk to each other. The staff is therefore very important in keeping the conversation between the patients flowing. When the staff is absent, it's usually quiet. The staff has an important function in creating a sense of security when patients sit together (P10).

The patients' DD made it more complicated to relate to each as an individual. One carer emphasized that this made the work challenging, but also interesting. Everything depended on the situation and the person. She said: "When you go into a room you can't follow a procedure, and say I am going to care for this patient in this way." (P14). One manager emphasized that this flexible approach to nursing was achievable, as it did not require additional resources. 
Another manager described how a patient's life story was brought into the conversation during personal care of a patient:

I myself experienced as a nurse, that when you are there during morning care, the patient has a carer with them, maybe three quarters of an hour. You talk about the day today, and what they have done earlier. It can be, not just personal care, but a pleasant experience (P12).

One of the managers said that if a patient resisted care and they knew of problems in the patient's past they could arrange fixed, familiar carers.

A couple of managers said that they experienced varying recognition in the staff for the importance of connections to the patient's life. One of them said: "Some of the staff are extremely interested and understand that the patient's restlessness can be related to things that have happened during the day, which are again related to the patient's own life" (P9). Some carers said that they did not have time to reflect about a patient's earlier life.

\section{A more challenging working day in the nursing home}

\section{Moving into the nursing home: Inadequate preparation}

Carers pointed out that they were poorly prepared when the patient moved into the nursing home: "Those of us working here, struggling with all this, are just told that this or that patient is coming." (P4). Carers would have liked to meet the patient at home, to have the same carers following up the patient for the first few days, and to have the patient's room furnished with familiar furniture and possessions before he or she arrived. When the nursing home had a vacancy, a new patient was quickly moved in: "We don't always have time to tidy and clean the room so that it is ready for the next day, when it has been decided that the patient is coming" (P12).

\section{A tighter framework}

All the managers and carers emphasized that patients' health when they came to the nursing home generally was poorer now compared to just a few years ago: "We treat them much more. Staffing 
levels have not increased correspondingly, so that the day to day work has changed" (P12). One manager said that patients were so ill when they came to the nursing home that "nothing is more important than making it through the day, getting enough sleep and rest, peace and quiet, so that you survive until tomorrow..." (P9).

Another manager said that public budget cutbacks had made it necessary to reduce staffing levels. They had to "get relatives in" and "use students" to a greater extent (P11). There was no time to sit down and talk to the patients. One unit manager added that when the unit was very unsettled, they were allowed to increase staffing levels.

\section{Substitutes and the need for nursing competence}

The increasing use of substitutes was challenging. One carer said that she had more than once experienced that conflicts arose between untrained carers and patients. One carer said: "If there's just one nurse at work, then you feel safe, you relax because you get help when you need it. But there are so many shifts without nurses" (P3).

\section{Discussion}

The interview methods are insufficient to document how nursing in the nursing homes was actually performed. The study is also limited to the nursing homes where it was carried out. Material from more nursing homes would probably give a broader understanding. The inclusion of one urban and one rural nursing home provided however a range of experiences and reflections. The nursing care of patients with DD in all nursing homes in Norway takes place within the same framework, legislation and guidelines, and one can assume that the results are to a large extent applicable to other nursing homes, an assumption that is supported by the authors' experience. There may however be regional variations. The inclusion of both nursing managers and nursing carers also provided a broader base for the findings. Although they were asked the same questions, the managers tended to emphasize the nursing home's long-term policy, while the carers concentrated 
more on everyday possibilities and challenges.

\section{Challenging situations - supporting belonging}

The carers in our study told that some patients were not interested in, or lacked the energy to take part in activities. This could be related to illness or weakness (30). In order to help the patient, carers must understand the development of DD (31). Patients with DD remember to varying degrees what they have done earlier in their lives $(2,11)$, and may have difficulties with activities they earlier enjoyed. The activity may remind the patient of what has been lost. If the patient does not remember, the activity is no longer familiar, but new each time, and can be exhausting. The patient often moves between these extremes. Carers must use discretion (23) to distinguish between what the patient is capable of, what gives an experience of loss, and what the patient can achieve with help. They must find the time that suits the patient best. Cooperation with family members is important. With good help and support to use their resources and abilities, patients can take part in some earlier activities and experience a continuity of identity.

Because of changes in both physical health and opportunities for activity, activity level can change or decrease after moving to a nursing home (32). This can also be an expression of natural positive withdrawal (33). "Engagement with life" (34) can include both activity and contemplation of life. Hope, belief and wisdom might be part of the activities of old age (13). Personal care is a situation where identity can be reinforced by focusing on these values. Carers can talk about subjects that are connected to the patient's life story, without necessarily expecting answers. The carer can sing, listen to the radio or say an evening prayer if it is meaningful for the patient.

Carers and managers in our study thought that restlessness or challenging behaviour could indicate unpleasant experiences in patients' lives. However if the patient does not understand what is happening, personal care can be experienced as abuse. The perspective of the person with DD must be taken into account (6). Feelings are still meaningful although people and incidents are forgotten 
(35). The carer must attempt to understand and relate to the patient's reactions together with the patient $(20,36)$. Challenging behaviour increases if patients feel they are struggling to be understood $(21,23)$.

\section{Local familiarity and belonging}

The participants in the study talked enthusiastically about their understanding of life story, belonging to a place, tradition, history and community. The sense of belonging and familiarity with people seemed consistent and central in the rural nursing home. Patients with DD in nursing homes in northern Norway and their relatives have described a close relationship to nature $(2,11)$. Carers and managers describe how a feeling of community is also important for patients' sense of security.

A high degree of shared belonging and familiarity between managers, carers, patients and relatives will affect patients' feeling of being at home in the nursing home $(37,38)$, and form an important foundation for nursing (9). Falk et al. (30) have shown that routines and rituals are important aspects of feeling at home, expressing facets of the person's identity formed through lifelong social interaction. Moving to a nursing home involves greater or lesser changes in personal daily routines, and the adjustment is particularly demanding for patients with DD. When managers and carers in the nursing home are aware of the connection between a patient's life story and the history and traditions of the district, they can affirm and support aspects of the patient's identity. Familiarity with local people and a sense of a local connection can give small rural nursing homes an advantage that should be taken into account in discussions about centralization of health services.

\section{Home visits: Getting to know the patient}

Managers in the urban area wished to get to know the patients before they moved to the nursing home. If possible, they would conduct a home visit, particularly to patients afflicted with DD, to 
collect some of the information the carers and managers in the rural area considered useful. Family members experienced the patient's move to a nursing home as a demanding transition $(11,39)$. If carers in the nursing home get to know the patient and relatives before moving, the transition may become easier to understand and deal with, and the experience as meaningful as possible for the patient. If a relationship of security and trust is achieved, the feeling may remain even if the patient does not remember the individual carers at the nursing home.

The patient about to move to a nursing home has usually received health and care services $(1,40)$, so that the development of the patient's illness and needs are known to the local health services before admission. It should therefore be possible to conduct a home visit and build a certain familiarity, also to patients without close relatives. The home give information about the person's life. Establishing a supportive relationship in this challenging phase of the patient's life can help to maintain a sense of belonging.

Before the patient moves to the nursing home, carers on a home visit can work with the patient and family members at documenting the patient's life story, which can be the basis for professional reflection in the nursing group. Listening to the patient's and relatives' narratives is crucial to become able to support the patient's identity in the nursing home, and requires time and competence (41).

Even though a home visit before admission to the nursing home is prioritised, it is not always feasible. The patient can be so ill that the admission must take place quickly. By inviting local inhabitants to events at the nursing home, elderly people become acquainted with the building, staff and patients there. A home visit requires competent staff if it is to function as intended. 


\section{Daily life - supporting belonging}

There are large individual variations in how a patient's earlier activities, habits, interests and values are expressed in daily life in the nursing home. Participants highlighted everyday activities that everyone takes part in. Carers need to consider how personal care or a meal can become a positive experience for each patient.

By guiding the conversation towards something that is meaningful for the patient, as far as appropriate for the situation, it is possible to create a "pleasant experience" during personal care of a patient. This might contribute to the patient's experience of continuity, by reminding him or her of activities, interests and values that were important in earlier life, and contribute to the patient's sense of belonging. Documentation and reflection in the nursing group allows carers who know the patient less well to use the possibilities in everyday conversation.

Conversational topics around the table at mealtimes were often seasonally related. The annual cycle of nature had shaped work and daily life of many of the patients (2). Mealtimes in the nursing home give an opportunity to get to know patients better and strengthen relationships and identity. Interviews with patients with DD in nursing homes show that they value traditional food (2). The social activity of a shared meal, serving of traditional food and conversations about traditions and stories from the local area, will support a sense of identity and belonging. Many family members make a big effort for their relatives in the nursing home, and some would be interested in participating more in social activities in the nursing home (11). Visiting family members should be invited to take part in mealtimes, or for example, encouraged to read from the local paper.

A group of patients with DD usually require the participation of competent carers to be able to have a conversation. According to Brooker (21), stress and confusion can be the result if carers do not 
have the competence to create a positive social environment for the patients. It is important to find a balance between confidentiality and an approach based on the individual's life.

\section{Competence in nursing homes - supporting person-centred nursing}

In this study, carers and managers talked about nursing care in nursing homes in a positive vein. This is not always the case (5). Carers in our study described managers as receptive and approachable. Managers ensured that carers had access to courses about DD and relevant literature. This reflects a professional management in line with person-centred nursing in DD. Managers and nurses have the main responsibility to ensure that person-centred nursing does not become empty words (Brooker, 21).

Our study reflect that there appeared to be limited time for counselling of carers and managers involved in person-centred DD nursing, and for reflection on how to strengthen a sense of belonging in patients with DD. Recognition of the importance of counselling and reflection was possibly also limited. One study found that student nurses experienced insufficient person-centred approach in the nursing of patients with DD (42). Transferring attitudes and knowledge to practice can be challenging, and managerial and counselling competence needs to be strengthened (43).

Carers said that they felt more secure when a nurse was at work. It may be that the nurse's expertise gives carers security in their daily work. Nurses need to have the opportunity to counsel carers with less expertise; particularly untrained staff, who need support if they are to take care of patients. Managers and health professionals would like to have access to guidance and advice about ethical issues in nursing homes (44). Situational leadership is appropriate since people and situations vary, requiring an individual approach (45). Managers must ensure that the carers are supported and empowered (46), in order to be able to give the best nursing care to the patient with DD. 


\section{Conclusion}

A patient's identity can be reinforced through measures in the nursing home that promote a sense of belonging. A home visit before the move to the nursing home is one such measure. In daily situations, such as personal care and mealtimes, carers can deliberately act and behave so as to support each patient's sense of identity. Differences in personality, background and DD development, and ill health of patients in nursing homes, make demands on professional assessment and expertise.

The values and attitudes that carers and managers emphasize are often challenged in the nursing home. Time and systematic effort is needed to promote professional nursing values. It is especially important that untrained and substitute staff are given continual support and guidance.

\section{Acknowledgements}

The authors wish to thank the managers who recruited participants and managers and nursing carers who took part in the study.

\section{References}

1. Helse- \& omsorgsdepartementet. Demensplan 2015 "Den gode dagen". Delplan til Omsorgsplan 2015. Revidert handlingsprogram for perioden 2012-2015.

http://www.regjeringen.no/pages/35878701/demensplan_2015.pdf (Accessed 18 September 2013)

2. Drageset, I., Normann, K., Elstad I. Personer med demenssykdom i sykehjem: Refleksjon over livet. Nordisk Tidsskrift for Helseforskning. 2013; Nr. 1, 9. årgang, 50-66.

3. Brooker, D. Person-centred dementia care. Making services better. London and Philadelphia: Jessica Kingsley Publishers; 2007.

4. McKeown, J., Clarke, A., Ingleton, C., Ryan, T., Repper, J. The use of life story work with people with dementia to enhance person-centred care. International Journal of Older People Nursing. 2010; 
$5,148-158$.

DOI: $10.1111 / \mathrm{j} .1748-3743.2010 .00219 . x$

5. Wadensten, B., Engholm, R., Fahlström, G., Hägglund, D. Nursing staff’s description of a good encounter in nursing homes. International Journal of Older People Nursing. 2009; 4, 203-210.

DOI: $10.1111 / \mathrm{j} .1748-3743.2009 .00170 . \mathrm{x}$

6. Cohen-Mansfield, J., Parpura-Gill, A., Golander, H. Salience of self-identity roles in persons with dementia: Differences in perceptions among elderly persons, family members and caregivers. Social Science \& Medicine. 2006; 62 (2006) 745-757.

DOI:10.1016/j.socscimed.2005.06.031

7. Moos, I., Björn, A. Use of life story in the institutional care of people with dementia: a review of intervention studies. Aging and Society. 2006; 26 (3), 431-454.

DOI: $10.1017 / \mathrm{S} 0144686 \mathrm{X} 06004806$

8. Brodaty, H., Draper, B., Low, L.-F. Nursing home staff attitudes towards residents with dementia: strain and satisfaction with work. Journal of Advanced Nursing. 2003; 44 (6), 583-590.

9. Zingmark, K., Sandman, P.-O., Norberg, A. Promoting a good life among people with Alzheimer's disease. Journal of Advanced Nursing. 2002; 38 (1), 50-58.

10. Cohen-Mansfield, J., Golander, H., Arnheim, G. Self-identity in older persons suffering from dementia: preliminary results. Social Science \& Medicine. 2000; 51 (2000) 381-394.

DOI:10.1016/S0277-9536(99)00471-2

11. Drageset, I., Normann, K., Elstad I. Familie og kontinuitet: Pårørende forteller om livsløpet til personer med demenssykdom. Nordisk Tidsskrift for Helseforskning. 2012; Nr. 1, 8. årgang, 3-19.

12. Fossland, T., Thorsen, K. Livshistorier i teori og praksis. Bergen: Fagbokforlaget; 2010

13. Erikson, E. H., Erikson, J. The Life Cycle Completed. Extended Version with New Chapters on the Ninth Stage of Development by Joan M. Erikson. New York/London; W. W. Norton \& Company; 1997

14. Erikson, E. H. Identity, Youth and Crisis. New York: W.W. Norton \& Company, Inc; 1968

15. Lorem, G. Psykisk helse. Forståelse, kommunikasjon og samspill. Oslo: Cappelen Damm AS; 2014

16. Synnes, O. Forteljing som identitet. Eit fors $\varnothing \mathrm{k}$ på å lese Paul Ricoeurs omgrep «narrativ identitet» i lys av alvorleg sjuke og døyande sine forteljingar. Tidsskrift for Teologi og Kirke ISSN 0040-7194, Vol 81, Nr 2. s. 129-147. Universitetsforlaget 2010

17. Kroger, J. Identity development. Adolescence Through Adulthood. Thousand Oaks, London, New Delhi: Sage Publications; 2007

18. Rokstad, A. M. M. Se hvem jeg er! Personsentrert omsorg ved demens. Oslo: Universitetsforlaget; 2014

19. McCormack, B., McCance, T. Person-Centred Nursing. Theory and Practice. Oxford, UK and Iowa, USA: Wiley-Blackwell; 2010 
20. McCormack, B. Person-centredness in gerontological nursing: an overview of the literature. International Journal of Older People Nursing in association with Journal of Clinical Nursing. 2004; 13, 3a, 31-38.

21. Brooker, D. What is person-centred care in dementia? Clinical Gerontology. 2003; 13, pp 215222.

DOI:10.1017/S095925980400108X

22. Kitwood, T. Dementia reconsidered, the person comes first. Buckingham and Philadelphia: Open University Press; 1997

23. Martinsen, K. Samtalen, skjønnet og evidensen. Oslo: Akribe; 2005

24. Martinsen, K. Omsorg, sykepleie og medisin. Historiske-filosofiske essays. Oslo: TANO; 1989

25. Wogn-Henriksen, K. "Du må ... skape deg et liv." En kvalitativ studie om å oppleve og leve med demens basert på intervjuer med en gruppe personer med tidlig debuterende Alzheimers sykdom. Avhandling for graden philosophiae doctor. Norges teknisk-naturvitenskapelige universitet, Fakultet for samfunnsvitenskap og teknologiledelse. Psykologisk institutt; 2012

26. Kvale, S. Det kvalitative forskningsintervju. Oslo: Gyldendal Akademisk; 2007

27. Wibeck, V. Fokusgrupper. Om fokuserade gruppintervjuer som undersökningsmetod. Lund: Studentlitteratur; 2000

28. Lundman, B., Graneheim, U. H. Kvalitativ innehållsanalys. I Granskär, M., \& Høglund-Nielsen, B. (red.). Tillämpad kvalitativ forskning inom hälso -och sjukvård. Lund; Studentlitteratur AB; 2012

29. Schreiner, M. Qualitative Content Analysis in Practice. Los Angeles; London; New Dehli; Singapore; Washington DC: SAGE Publications Ltd; 2012

30. Falk, H., Wijk, H., Persson, L-O., Falk, K. A sense of home in residential care. Scandinavian Journal of Caring Sciences. 2012; Dec;27 (4), 999-1009.

DOI: $10.1111 /$ scs. 12011

31. Edberg, A.-K. Att möta personer med demens. In Edberg, A.-K. (red.). Att möta personer med demens. Lund: Studentlitteratur; 2011

32. Cipriani J., Faig S., Ayrer K., Brown L., Johnson, N. C. Altruistic Activity Patterns Among Long-Term Nursing Home Residents. Physical and Occupational Therapy in Geriatrics. 2006; Vol 24(3); 45-61.

DOI:10.1300/J148v24n03_04

33. Tornstam, L. Gerotranscendence: The Contemplative Dimension of Aging. Journal of Aging Studies. 1997; Volume 11, Numer 2, pages 143-154.

DOI:10.1016/S0890-4065(97)90018-9

34. Rowe, J. R., Kahn, R. L. Successful Aging. The Gerontologist. 1997; Vol. 37, No. 4, 433-440.

35. Magai, C., Cohen, C., Gomberg, D., Malatesta, C., Culver, C. Emotional Expression During 
Mid- to Late-Stage Dementia. International Psychogeriatrics. 1996; Vol. 8, No 3, 383-395.

36. Antonovsky, A. Unraveling the Mystery of Health: How People Manage Stress and Stay Well. A joint publication in The Jossey-Bass Social and Behavioural Science Series and The Jossey-Bass Health Series. San Francisco: Jossey-Bass Inc., Publishers and London: Jossey-Bass Limited; 1987.

37. Cooney, A. 'Finding home': a grounded theory on how older people 'find home' in long-term care settings. International Journal of Older People Nursing. 2012; 7, 188-199.

DOI: $10.1111 / \mathrm{j} .1748-3743.2011 .00278 . x$

38. Zingmark, K., Norberg, A., Sandman, P.-O. The Experience of being at home throughout the life span. Investigation of persons aged from 2 to 102. The International Journal of Aging and Human Development. 1995; Vol. 41 (1) 47-62.

39. Lee, V., Simpson, J., Froggatt, K. A narrative exploration of older people's transitions into residential care. Aging and Mental Health. 2013; Vol. 17, No.1, 48-56.

DOI: 10.1080/13607863.2012.715139.

40. Helse- \& omsorgsdepartementet. Stortingsmelding nr 47 (2008-2009). Samhandlingsreformen. Rett behandling - på rett sted - til rett tid. http://www.regjeringen.no/nb/dep/hod/dok/regpubl/stmeld/2008-2009/stmeld-nr-47-2008-2009html?id=567201 (Accessed 12 June 2013)

41. Normann, H. K., Norberg, A., Asplund, K. Confirmation and lucidity during conversations with a woman with severe dementia. Journal of Advanced Nursing. 2002; 39(4), 370-376.

42. Skaalvik, M. W., Normann, H. K., Henriksen, N. Student experiences in learning person-centred care of patients with Alzheimer's disease as perceived by nursing students and supervising nurses. Journal of Clinical Nursing. 2010; 19, 2639-2648.

DOI: $10.1111 / \mathrm{j} .1365-2702.2010 .03190 . \mathrm{x}$

43. Helse- \& omsorgsdepartementet. St. meld nr. 25 (2005- 2006). Mestring, muligheter og mening. Framtidas omsorgsutfordringer http://www.regjeringen.no/Rpub/STM/20052006/025/PDFS/STM200520060025000DDDPDFS.pdf (Accessed 19 June 2013)

44. Bolling, G., Pedersen, R., Førde, R. Etikk i sykehjem og hjemmetjenester. Sykepleien Forskning nr 3, 2009; 4:186-196.

45. Lynch, B. M., McCormack, B., McCance, T. Development of a model of situational leadership in residential care for older people. Journal of Nursing Management, 2011; 19, 1058-1069.

DOI: $10.1111 / \mathrm{j} .1365-2834.2011 .01275 . x$

46. Caspar, S., O'Rourke, N. The Influence of Care Provider Access to Structural Empowerment on Individualized Care in Long-Term-Care Facilities. Journal of Gerontology: Social Sciences. 2008; Vol. 63B, No. 4, 255-265. 